\title{
THE CRIMINAL RESPONSIBILITY FOR THE GENOCIDE AND THE CRIME AGAINST HUMANITY ACCORDING TO THE ROME STATUTE (VIEW ON THE NEW SERBIAN CRIMINAL CODE)
}

\author{
Dragan Jovašević \\ University of Niš, Faculty of Law, Republic of Serbia
}

International criminal law, as a system of legal regulations found in acts of the international community and criminal legislation of individual states, establishes criminal liability and punishments for crimes against international law. These acts represent a breach of the laws and customs of war (international humanitarian law) that violate or threaten peace among nations and the security of mankind. Penalties prescribed for these criminal offences stand for the most severe penalties in contemporary criminal legislation. In some cases, international judiciary (supranational) institutions such as the Hague Tribunal (ICTY) and the other international military and ad hoc tribunals or courts have primary jurisdiction over perpetrators of these criminal offences.

Crime against humanity defined in paragraph 371. of the New Criminal Code of the Republic of Serbia (2005), represents a newly introduced criminal offence, ${ }^{1}$ whose establishment is related to the Statute of the International Military Tribunal from 1945 and the Nürnberg Judgment. It is a serious crime against international law that threatens characteristic values of the entire mankind, or values that are considered as generally humane. The development of the concept of crime against humanity was predominantly influenced by the idea of the need to protect fundamental human rights and freedoms. Crime against humanity (crimen iuris gentium) is based upon violations of fundamental laws of humanity, i.e. each person's right to life and the right of each ethnical group to exist as such. In legislation, theory and practice, this term can be interpreted in the

\footnotetext{
* Dragan Jovašević, Ph. D, Full Professor.

${ }^{1}$ Previous absence of this incrimination has been justified by the fact that it has been covered by the crime of genocide. However, contemporary practice related to the civil war in the territory of former Yugoslavia indicates that some crimes against civilian population cannot be treated as genocide since they are not aimed to destroy, in whole or in part, a national, racial, religious or ethnical group, whereas the time of their perpetration does not allow them to be considered as war crimes against civilian population.
} 
broader sense, as well. In this paper the author has analyzed theoretical and practical aspects of crime against humanity in international criminal law and new criminal law of the Republic of Serbia (former FR Yugoslavia).

Key Words: international law, humanity, crime, court, responsibility, penalty

\section{Preface}

In the legal system of the Republic of Serbia, crimes against international law are enuImerated in the Chapter Thirty Four of the Criminal Code ${ }^{2}$, entitled "Criminal Offences against Humanity and Other Rights Guaranteed by International Law". These criminal offences actually represent acts that constitute violations of international treaties, agreements and conventions and threaten and entrench peace among nations, the security of mankind and other values protected by international law or are in breach of the rules of war related to the treatment of war prisoners, wounded, sick and civilians by the parties to the conflict.

The origination of these criminal offences is related to the establishment of international rules organizing relations between states in time of war and relations between the parties to the conflict in view of commencement and conduct of armed conflict. International law of war emerged as the consequence of cruel and inhumane comportment throughout the long history of wars and armed conflicts between nations and states, with the intention to humanize this most inhumane means of resolving international and inter-state disputes.

Along with the expansion of the international law of war, the process of gradual limitation of the rights that belong to the parties to the conflict started, as well as the process of controlling not only the acts committed against non-combatants, but also those related to the commencement and conduct of war. State's right of absolute freedom to commence and conduct a war will gradually be reduced by prohibiting certain acts that include unnecessary devastation, killing and torture. Breaches of the laws and customs of war constitute crimes under the laws of war. Having accepted international obligations by signing and ratifying numerous international conventions, certain states included several criminal offences against humanity and other rights guaranteed by international law in their criminal legislation. Such criminal offences are committed by violating rules contained in international conventions. Their source lays in the prohibitions proclaimed in international legal documents (acts) ${ }^{3}$.

The subject of protection according to international criminal law ${ }^{4}$ consists of humanity and other universally recognized and generally accepted values protected by international law. The protection of humanity pertains to the protection of essential human rights such as life, physical integrity, honor, reputation, personal dignity and other fundamental human rights and freedoms. Additional rights that belong to natural persons, individual states and the entire international community are also of general, universal significance and therefore protected and guaranteed by international law.

\footnotetext{
${ }^{2}$ Official Gazette of the Republic of Serbia, No. 85/2005, 88/2005, 107/2005, 72/2009, 111/2009, 104/2012, 108/2014 and 94/2016. More: D. Jovašević, Krivični zakonik Republike Srbije sa uvodnim komentarom, Beograd, 2007.

${ }^{3} \mathrm{~S}$. Zadnik, Kaznena djela protiv vrijednosti zaštićenih međunarodnim pravom i novine u zakonodavstvu u svezi sa tim djelima, Hrvatska pravna revija, Zagreb, No. 12, 2003. pp. 83-86.

${ }^{4}$ D. Jovašević, Leksikon krivičnog prava, Beograd, 2011, p. 345.
} 
The Criminal Responsibility for the Genocide and the Crime against Humanity According ...

The majority of crimes against the international law ${ }^{5}$ can be committed only in a certain period of time determined by the law: during war, armed conflict or occupation. These criminal offences are most commonly committed in an organized manner with the aim to implement certain governing group's or party's politics. Being considered as an aspect of organized, planned criminality, these offences are most frequently committed by the order of superior military or political leaders. Due to that, it is necessary to determine individual criminal responsibility of organizer, order-giver and offender.

These criminal offences can be committed only by premeditation. Some of the criminal offences in this group are not subject to limitations on criminal prosecution and limitations on enforcement of penalty: genocide, crime against humanity, war crimes and other criminal offences that pursuant to ratified international treaties cannot be subject to limitations.

\section{The system of international crimes}

The theory of international criminal law recognizes several sorts of crimes against international law. They are most commonly divided into two categories $\left.{ }^{6}: 1\right)$ crimes against international law in the narrow sense (genuine or pure crimes against international law) and 2) crimes against international law in the broader sense, or transnational crimes (counterfeit or mixed). This classification was adopted for the first time at the 14th Congress of the International Criminal Law Association that took part in Vienna in 1989. The criterion of the division is the jurisdiction of international criminal courts, which is established only in the case of crimes against international law in the narrow sense.

Crimes against international law ${ }^{7}$ in the narrow sense belong to the first group of these criminal acts. These crimes against international law represent violations of laws and customs of war (meaning the rules of international law of war and international humanitarian law). They are incorporated in the Judgments of the Nürnberg and the Tokyo Tribunal, and they are also known as criminal offences under general international law (or crimina iuris gentium).

The following criminal offences can be placed in this category $\left.{ }^{8}: 1\right)$ crime against peace, 2) war crimes, 3) genocide and 4) crime against humanity. In legal theory, there are opinions suggesting that these criminal offences should be referred to as international crimes stricto sensu that are prohibited by cogent rules of international law such as the Hague or the Geneva Conventions ${ }^{9}$.

The following features of crimes against humanity in the broader sense (core crimes) are pointed out in legal theory ${ }^{10}$ :

1) These international crimes have double-layered nature. Their commission draws the following consequences:

\footnotetext{
${ }^{5}$ D. Jovašević, Međunarodno krivično pravo, Niš, 2011. pp. 45-57.

${ }^{6}$ More: Ch. M. Bassiouni, Crimes against Humanity in International Criminal Law, Dordrecht, 1992.

${ }^{7}$ B. Petrović, D. Jovašević, Međunarodno krivično pravo, Sarajevo, 2010. pp. 252-258.

${ }^{8}$ D. Jovašević, V. Ikanović, Međunarodno krivično pravo, Banja Luka, 2015. pp. 272-278.

${ }^{9}$ V. Đ. Degan, B. Pavišić, Međunarodno kazneno pravo, Zagreb, 2005. pp. 186-187.

${ }^{10}$ D. Radulović, Međunarodno krivično pravo, Podgorica, 1999. p. 103.
} 
a) Individual criminal liability, either of a perpetrator, or of an accomplice, or of a superior (on the grounds of superior liability), on the one hand, and

b) The responsibility of a state under international law, on the other.

2) International crimes violate essential (fundamental) human rights and they are therefore prohibited as repression against the same crimes committed by the opposite party.

3 ) International crimes are not subject to limitations on criminal prosecution and limitations on enforcement of penalty.

4) General international law imposes as an erga omnes obligation on the states not to breach the basic rules that prohibit these acts.

\section{The genocide and the crime against humanity according to the rome statute}

The Rome Statute of the International Criminal Court, adopted on OUN diplomatic conference that took part in Rome on July 17 1998, states that the court will exercise jurisdiction over conducting criminal procedure, determining criminal liability and imposing criminal sanctions on persons, who have committed crimes recognized as the most serious by the international community as a whole.

Paragraph 5 of the Statute proclaims the jurisdiction of the Court with respect to the following crimes ${ }^{11}$ : 1) the crime of genocide, 2) crimes against humanity, 3 ) war crimes, and 4) the crime of aggression.

According to Paragraph 77 , the Court may impose one of the following penalties on the perpetrator of some of these criminal offences ${ }^{12}$ :

1) imprisonment for a specified number of years, which may not exceed a maximum of 30 years,

2) a term of life imprisonment when justified by the extreme gravity of the crime and the individual circumstances of the convicted person,

3) a fine under the criteria provided for in the Rules of Procedure and Evidence and

4) forfeiture of proceeds, property and assets derived directly or indirectly from the crime committed.

\section{The notion and basic characteristics of genocide}

The crime of genocide ${ }^{13}$ is defined in Paragraph 6 of the Statute. This criminal act ${ }^{14}$ is committed with intent to destroy, in whole or in part, a national, ethnical, racial or religious group ${ }^{15}$, in one of the following ways ${ }^{16}$ :

\footnotetext{
${ }^{11}$ D. Jovašević, Krivično pravo, Opšti deo, Beograd, 2016. pp. 70-75.

${ }^{12}$ V. Đurđić, D. Jovašević, Međunarodno krivično pravo, Beograd, 2003. pp. 78-87.

${ }^{13}$ A part of legal theory does not consider genocide as an autonomous criminal offence, and only as a type of crime against humanity.

${ }^{14}$ Genocide is determined as "the crime above all crimes". The prohibition of committing this criminal offence or of inciting others to do so represents ius cogens. Therefore, unlawfulness of the genocidal activities, as well as the actual criminal character of these acts, is generally accepted as indisputable by the international community.
} 
The Criminal Responsibility for the Genocide and the Crime against Humanity According ...

1) by killing members of the group ${ }^{17}$,

2) by causing serious bodily or mental harm to members of the group,

3 ) by deliberately inflicting on the group conditions of life calculated to bring about its physical destruction in whole or in part,

4) by imposing measures intended to prevent births within the group and

5) by forcibly transferring children from one group to another ${ }^{18}$.

\section{The notion and basic characteristics of crime against humanity}

Paragraph 7 of the International Criminal Court Statute ${ }^{19}$ is dedicated to crime against humanity ${ }^{20}$. The Rome Statute makes distinction between this criminal offence and the crime of genocide, although in the times when crime against humanity entered the system of international incrimination, there were standpoints in legal theory that treated these two terms as identical. Crime against humanity includes acts committed as a part of a widespread or systematic attack ${ }^{21}$ directed against any civilian population ${ }^{22}$.

For the purpose of this criminal offence, an attack can consist of the following acts ${ }^{23}$ :

1) murder,

2) extermination,

3) enslavement - the exercise of the powers attached to the right of ownership over a person,

4) deportation or forcible transfer of population- forced displacement of the persons from the area in which they are lawfully present,

5) imprisonment or other severe deprivation of physical liberty in violation of fundamental rules of international law,

6 ) torture - the intentional infliction of severe pain or suffering, whether physical or mental, upon a person deprived of liberty,

7) rape, sexual slavery, enforced prostitution, forced pregnancy, enforced sterilization, or any other form of sexual violence,

\footnotetext{
${ }^{15}$ This incrimination provides protection only for stable groups of permanent character, whose member one can become by birth, while excluding unstable (inconsistent) groups, where membership is based upon individual decision. This is also the standpoint of the International Criminal Tribunal for Rwanda in the Akayese case.

${ }^{16}$ D. Jovašević, Krivično pravo, Posebni deo, Beograd, 2017. pp. 280-282.

${ }^{17}$ A larger number of victims are not essential for the completion of genocide. Actually, killing one or several persons is considered as sufficient. Genocide can be committed by a single individual, as well, as long as he acts with the genocidal intent, provided that his behavior, correspondent to other similar behaviors, is of such character that makes it suitable to contribute to the extermination of the entire group.

${ }^{18}$ B. Pavišić, T. Bubalović, Međunarodno kazneno pravo, Rijeka, 2013. pp. 283-291.

${ }^{19}$ More: I. Josipović, D. Krapac, P. Novoselec, Stalni međunarodni kazneni sud, Zagreb, 2001.

${ }^{20}$ D. Jovašević, Međunarodna krivična dela - odgovornost i kažnjivost, Niš, 2010. pp. 242-244.

${ }^{21}$ It is deemed that such attack consists of the attack committed within the state's politics or in order to complete the aims of some other organization. The attack does not necessarily have to be of military nature. This criminal offence can be perpetrated in times of war, as well as in times of peace. Consequently, isolated and individual attacks are not covered by this incrimination.

${ }^{22}$ The victim of this crime is not an individual person, but the entire mankind.

${ }^{23}$ P. Novoselec, Opći dio kaznenog prava, Zagreb, 2004. pp. 499-500.
} 
8) persecution against any identifiable group or collectivity on political, racial, national, ethnic, cultural, religious, gender or other grounds that are universally recognized as impermissible under international law - deprivation of recognized fundamental rights of a group,

9) causing disappearance of persons (enforced disappearance of persons),

10 ) the crime of apartheid - inhumane acts committed in the context of an institutionalized regime and

11) other inhumane acts intentionally causing great suffering, or serious danger to mental or physical health ${ }^{24}$.

\section{The genocide and the crime against humanity according to the criminal code of the republic of serbia from 2005}

\section{The system of international crimes in the Serbian criminal law}

Chapter 34 of the new Criminal Code of the Republic of Serbia from 2005 contains the following "genuine" crimes against international law ${ }^{25}$ :

1) genocide (Paragraph 373),

2) crime against humanity (Paragraph 371 ),

3) war crime against civilian population (Paragraph 372),

4) war crime against the wounded and sick (Paragraph 373),

5) war crime against prisoners of war (Paragraph 374), and

6) organization and incitement to genocide and war crimes (Paragraph 375 ).

\section{Genocide - notion and basic characteristics}

The crime of genocide ${ }^{26}$, from Paragraph 370 of the Criminal Code of the Republic of Serbia, consists of ordering or committing the following acts: killing or causing serious bodily or mental harm to members of the group, deliberately inflicting on the group conditions of life calculated to bring about its physical destruction in whole or in part, imposing measures intended to prevent births within the group, forcibly transferring children of the group to another group, with intent to destroy, in whole or in part, a national, ethnical, racial or religious group of people.

The word "genocide" is a compound, created from a Greek word genos, meaning nation or tribe, and a Latin word caedes, which means killing or slaughter (massacre). When translated literally this word stands for the extermination of an entire nation or tribe. Genocide was proclaimed as "a crime against international law, which is in contra-

\footnotetext{
${ }^{24}$ More: A. Cassese, P. Gaeta, J. R. W. Jones, The Rome Statute of the International Criminal Court - Commentary, Oxford, New York, 2002.

${ }^{25}$ V. Đurđić, D. Jovašević, Krivično pravo, Posebni deo, Beograd, 2012. pp. 322-345.

${ }^{26}$ B. Petrović, D. Jovašević, Krivično (kazneno) pravo II, Posebni dio, Sarajevo, 2005. pp. 39-42.
} 
The Criminal Responsibility for the Genocide and the Crime against Humanity According ...

diction with the spirit and the aims of the OUN and condemned by the entire civilized world" by OUN General Assembly Resolution 96/1 from 11 December $1946^{27}$.

In spite of the fact that it initially emerged as a "subspecies of crime against humanity", genocide rapidly obtained autonomous status and contents as one of the most serious crimes today. Nowadays, it is also called "the crime above all crimes". As a crime against international law, genocide is determined by three elements ${ }^{28}$ :

1) the objective component - actus reaus,

2) the subjective component - mens rea and

3 ) the subject of the act - the victim (the group).

The source of this incrimination is found in Convention on the Prevention and Punishment of the Crime of Genocide from 1948, which defines the contents and the elements of this crime against international law.

In legislation, theory and practice this term has a more extensive interpretation. Namely, this expression includes not only killing, but also extermination, committed in any other way, of a particular group that forms a consistent entity based upon national, ethnical, racial or religious foundation. The subject of protection includes humanity and international law.

The subject of attack is a national, ethnical, racial or religious group. A national group is comprised of people who have the feeling of sharing the legal bond of the same citizenship accompanied by reciprocal rights and obligations. An ethnical group consists of the members who are bound by the same language and culture, whereas a racial group is a group based upon hereditary physical characteristics, which is often associated to a particular geographical area regardless of linguistic, cultural, national, or religious factors. A religious group includes members, who share the same religious convictions, the same name of the confession or the same means of conducting religious ceremonies. In fact, the terms such as national, ethnical, racial or religious group are still studied widely and precise definitions that would be universally and internationally accepted have not been found yet. Thus, each of these terms has to be assessed in the light of an actual political, social and cultural milieu.

Although the act ${ }^{29}$ is committed by destroying individuals, it is not intended to eliminate those individuals as separate persons, but as members of a group. Therefore, the aim of the act is to destroy a group, in whole or in part, whereas elimination of an individual simply represents means of its accomplishment. The size of a group is of no significance for completion of the criminal offence. It is essential that a group is present as an entity that has specific characteristics, and that it is intended to be destroyed as such.

\footnotetext{
${ }^{27}$ Official Gazette of the SFR Yougoslavia, No. 56/1950.

${ }^{28}$ B. Petrović, D. Jovašević, A. Ferhatović, Krivično pravo 2, Sarajevo, 2016. pp. 305-309.

${ }^{29}$ Depending on the actual subject, genocide can appear as national or ethnical (ethnocide) if the subject is a national or ethnical group. In the case of racial genocide, the criminal act is directed against a particular racial group or against several groups of that kind. Religious genocide is directed against the members of one or more religious groups. The group is not to be determined in accordance with an objective or static criterion. Instead, the way the perpetrator perceives the members of the group is of fundamental importance for the definition of this term, which is also the standpoint of the ad hoc tribunals. The lack of definitions of genocide that would include cultural genocide comprised of destroying the language or the culture of a particular group is often stressed in legal theory.
} 
The objective of incrimination is to guarantee the right to life, i.e. existence and development for each group that has specific national, ethnical, racial or religious features, regardless of spatial cohesion of its members.

The act consists of several acts that can be classified in a number of groups. These are the following acts ${ }^{30}$ :

1) killing or causing serious bodily or mental harm to members of a specific national ethnical, racial or religious group,

2) inflicting on the group conditions of life calculated to bring about its physical destruction in whole or in part,

3) imposing measures intended to prevent births within the group (the so-called biological genocide) and

4) forcible transfer of children from one group to another intended to cause the loss of their group identity.

All these acts contribute to physical and biological completion of genocide. To complete this act, it is enough to commit any of the acts precisely pointed out in the law, with the intent to exterminate (destroy), in whole or in part, a group as a social entity. Genocide represents a typical example of criminal offences that rest upon the "depersonalization of the victim", which means that the victim does not represent the objective (aim) of the act due to its individual qualities or features, but and solemnly for being a member of a certain group.

The perpetration can be completed in two ways ${ }^{31}: 1$ ) by ordering and 2) by directly conducting certain acts.

Giving orders to commit the abovementioned acts represents a special and autonomous act of genocide. In fact, ordering is a form of incitement. However, in this case ordering is not characterized as complicity, but as a special way to perpetrate this criminal offence. The crime of genocide is usually committed in an organized manner and in accordance with a previously arranged plan giving particular authority to the order of a superior, which causes the autonomous nature of their responsibility. Therefore, the superior will be responsible only for having given the order to commit genocide, even if the subordinate refuses to obey or in any other way manages to avoid executing such order ${ }^{32}$.

The consequence of the act is manifested as threatening the survival of a certain national, ethnical, racial or religious group. It can be accomplished through causing a smaller or larger number of individual consequences comprised of injuries (of life, physical integrity, a fetus) and threats (by inflicting on the group unbearable living conditions). The number of individual acts committed is of no significance for completion of this criminal offence. This means that only an act of genocide will be committed when one, as well as several relevant acts, has been conducted. The fact that a larger number of acts causing various individual consequences have been committed has an impact on determination of sentence. This indicates that planned and systematic extermination of human groups constitutes the essence of the crime of genocide ${ }^{33}$.

\footnotetext{
${ }^{30}$ LJ. Lazarević, B. Vučković, V. Vučković, Komentar Krivičnog zakonika Crne Gore, Cetinje, 2004. pp. 1021-1023.

${ }^{31}$ B. Pavišić, V. Grozdanić, P. Veić, Komentar Kaznenog zakona, Zagreb, 2007. pp. 419-421

32 D. Jovašević, Lj. Mitrović, V. Ikanović, Krivično pravo Republike Srpske, Posebni deo, Banja Luka, 2017. pp. 359-365.

${ }^{33}$ K. Turković et al., Komentar Kaznenog zakona, Zagreba, 2013. pp. 133-137.
} 
The Criminal Responsibility for the Genocide and the Crime against Humanity According ...

Any person can be the perpetrator of this act, and, when guilt is concerned, direct premeditation (dolus coloratus) ${ }^{34}$, including the genocidal intent, is required. Instead of applying the theory of intent, the assessment of such intent is based upon experience. The punishment prescribed for this act is minimum five years' imprisonment or thirty to forty years' imprisonment. The Criminal Code explicitly points out that this criminal act cannot be subject to limitation for criminal prosecution and enforcement of penalty.

\section{The crime against humanity - notion and basic characteristics}

Crime against humanity ${ }^{35}$, defined in Paragraph 371 of the New Criminal Code of the Republic of Serbia $(2005)^{36}$, represents a newly introduced criminal offence, ${ }^{37}$ whose establishment is related to the Statute of the International Military Tribunal from 1945 and the Nürnberg Judgment ${ }^{38}$. It is a serious crime against international law that threatens characteristic values of the entire mankind, or values that are considered as generally humane. The development of the concept of crime against humanity was predominantly influenced by the idea of the need to protect fundamental human rights and freedoms.

Crime against humanity (crimen iuris gentium) is based upon violations of fundamental laws of humanity, i.e. each person's right to life and the right of each ethnical group to exist as such.

Accordingly, the acts in question are directed against the conditions that are essential for the survival of a human being, individual human groups and mankind as a whole. Therefore, legal theory points out the following elements of crimes against humanity ${ }^{39}$ :

1) the latter are considered as particularly abhorrent violations that seriously offend human dignity and cause humiliation of one or several persons,

2) these crimes are not isolated or sporadic cases, and are committed as a part of certain state governmental politics or as an extensive or systematic practice, which is tolerated, pardoned or accepted, either by the official government or by the unofficial (de facto) regime,

3) the acts in question are prohibited and punishable whether committed in war or in peace, and

\footnotetext{
${ }^{34}$ F. Bačić, Krivično pravo, Posebni deo, Zagreb, 1986. p. 316.

${ }^{35}$ V. Đ. Degan, B. Pavišić, V. Beširević, Međunarodno i transnacionalno krivično pravo, Beograd, 2013. pp. 304-316.

${ }^{36}$ Official Gazette of the Republic of Serbia, No. 85/2005, with more novels to 2016. More: D. Jovašević, The Criminal code of the Republic of Serbia with commentary, Belgrade, 2007.

${ }^{37}$ Previous absence of this incrimination has been justified by the fact that it has been covered by the crime of genocide. However, contemporary practice related to the civil war in the territory of former Yugoslavia indicates that some crimes against civilian population cannot be treated as genocide since they are not aimed to destroy, in whole or in part, a national, racial, religious or ethnical group, whereas the time of their perpetration does not allow them to be considered as war crimes against civilian population.

${ }^{38}$ It is assumed that one of the first judgments dealing with crime against humanity is the judgment of the Special Court of Cassation of Holland from 1949, saying that the characteristics of the crimes of this category include gravity and ferociousness, large extensions, the fact that they represent a part of the system aimed to spread terror or a link to politics deliberately conducted against some groups of population.

${ }^{39}$ D. Jovašević, Krivično pravo, Posebni deo, Beograd, 2017. pp. 324-325.
} 
4) the victims of this crime can be civilians, or, if committed during an armed conflict, persons who do not participate or who no longer participate in the conflict, as well as the combatants of the opposite party, in accordance with international customary law.

This criminal offence is committed if a person, in violation of the rules of international law, as part of a wider ${ }^{40}$ and systematic ${ }^{41}$ attack against civilian population ${ }^{42}$ orders or commits: murder, inflicting on the group conditions of life calculated to bring about its complete or partial extermination ${ }^{43}$, enslavement, deportation, torture, rape, forcing to prostitution, forcing pregnancy or sterilization aimed at changing the ethnic balance of the population, persecution ${ }^{44}$ on political, racial, national, ethical, sexual or other grounds, detention or abduction of persons without disclosing information on such acts in order to deny such person legal protection, oppression of a racial group or establishing domination of one group over another, or other similar inhumane acts that intentionally cause serious suffering or serious endangering of human health.

The subjects of protection are humanity and international law.

The subject of the attack is civilian population, i.e. members of the entire noncombating population regardless of their citizenship, who found themselves on the occupied territory or territory under the regime of the opposite party. Although this criminal offence is committed by conducting certain acts against individuals, its aim is not to eliminate those individuals as particular persons, but to contribute to the conduct of a wider or systematic attack directed against the entire civilian population.

Accordingly, the intent is to destroy (exterminate) the entire or the majority of civilian population, whereas the elimination of individuals represents only means of accomplishing this intent. Namely, it refers to acts repeatedly committed against civilians on grounds of or with the intent to realize particular state's politics or the politics of a certain organization (e.g. a political party or similar organization). The aim of this incrimination is to ensure every person's right to life along with providing respect of fundamental human rights and freedoms.

The criminal act is comprised of a series of diverse acts that can be divided into several categories ${ }^{45}$ :

1. Killing another person-murder,

2. Inflicting on population or its part conditions of life calculated to bring about its complete or partial extermination ${ }^{46}$,

\footnotetext{
${ }^{40}$ The term "wider attack" should be interpreted as the fact that an armed conflict takes place in a broader territory.

${ }^{41}$ The term "systematic attack" should be interpreted as a planned attack, where an arrangement has previously been achieved and certain directions given. The plan can be incorporated in a broader military or political plan, and it can also be related to particular operations.

${ }^{42}$ The attack directed against civilian population signifies the behavior that includes repeated perpetration of the acts enumerated in the law against any civilian population, on the grounds or with the aim of certain state's politics or the politics of an organization to commit such attack.

${ }^{43}$ Extermination includes deliberately imposing such conditions, especially deprivation of access to food and medicaments, which can cause the destruction of a part of population.

${ }^{44}$ Persecution can be related to any group of people or community on political, racial, national, ethnical, cultural, religious, sexual, or other grounds, which is universally recognized as unacceptable in international law with regard to any criminal act. This situation includes deliberate and severe deprivation, or denial of fundamental human rights and freedoms due to the membership in a particular group of people or community, which is in contradiction to international law.

${ }^{45}$ B. Petrović, D. Jovašević, krivično (kazneno) pravo II, Posebni dio, Sarajevo, 2005. pp. 42-44.
} 
The Criminal Responsibility for the Genocide and the Crime against Humanity According ...

3. Enslavement or compulsory deportation of the population

4. Torture,

5. Rape, forcing to prostitution, forcing pregnancy or sterilization aimed at changing the ethnic balance of the population

6 . Persecution ${ }^{47}$ grounded on political, racial, national, ethical, cultural, sexual or other grounds,

7. Detention or abduction of persons without disclosing information on such acts in order to deny such person legal protection,

8. Oppression of a racial group or establishing domination of one group over another,

9. Other similar inhumane acts that intentionally cause serious suffering or seriously endanger human health.

The criminal act can be perpetrated in two ways ${ }^{48}: 1$ ) by ordering and 2) by directly committing the act. Giving order to commit the previously mentioned acts represents a particular and autonomous act of crime against humanity.

In general, ordering represents a form of incitement. However, in this case it is not treated as complicity, but as a special way to commit this criminal offence. This criminal offence is usually committed in an organized and systematic manner in accordance with a previously designed plan, giving special power to the order of a superior, which causes the autonomous nature of its criminal responsibility. To be exact, the superior will be responsible for having ordered crime against humanity to be committed even if the subordinate refused or in any other way avoided to obey such order.

It is essential for the criminal act that one or more acts are committed repeatedly ${ }^{49}: 1$ ) by violating rules of international law and therefore unlawfully, which the perpetrator has to be aware of and 2) as part of a wider and systematic attack directed against any part of civilian population.

Taking into consideration grammatical interpretation of this paragraph, one might conclude that this criminal offence can be committed only during an armed conflict („within the attack"), which is incorrect. It is more appropriate to assume that crimes of this kind can be committed during, as well as after an armed conflict, as long as the criminal acts are being perpetrated in the context of wider or systematic attack directed against civilian population ${ }^{50}$.

The consequence of the act emerges as an injury or deprivation of fundamental human rights and freedoms of civilian population. It can be completed by causing a

\footnotetext{
${ }^{46}$ Extermination includes deliberately imposing such conditions, especially deprivation of access to food and medicaments, which can cause the destruction of a part of population.

${ }^{47}$ Persecution can be related to any group of people or community on political, racial, national, ethnical, cultural, religious, sexual, or other grounds, which is universally recognized as unacceptable in international law with regard to any criminal act. This situation includes deliberate and severe deprivation, or denial of fundamental human rights and freedoms due to the membership in a particular group of people or community, which is in contradiction with international law.

${ }^{48}$ Z. Pajić, Tumačenje zločina protiv čovečnosti u nirnberškom procesu, Godišnjak Pravnog fakulteta u Sarajevu, Sarajevo, 1991. pp. 123-133.

${ }^{49}$ D. Jovašević, Međunarodna krivična dela - odgovornost i kažnjivost, Niš, 2010. pp. 263-265.

${ }^{50}$ M. Milojević, Zločin protiv čovečnosti u rezolucijama Generalne skupštine UN, Godišnjak Pravnog fakulteta u Sarajevu, Sarajevo, 1978. pp. 225-243.
} 
smaller or larger amount of individual consequences. The number of individual consequences does not influence the existence of criminal offence. However, it has an impact on the determination of punishment.

Each person can be the perpetrator of this criminal offence, and, when guilt is concerned, direct premeditation is required.

The punishment prescribed for this criminal act is minimum five years' prison or thirty to forty years' prison.

The Criminal Code of the Republic of Serbia explicitly points out that this criminal offence is not subject to limitations on criminal prosecution and limitations on enforcement of penalty.

\section{The responsibility in international criminal law}

\section{Responsibility of a natural person - notion and elements}

Criminal responsibility ${ }^{51}$ of individuals as natural persons under international criminal law includes a group of subjective circumstances that determine the mental state of the perpetrator and his psychological attitude towards the crime against international law he has committed. Due to such circumstances, the perpetrator can be considered as mentally competent and guilty. Accordingly, criminal liability under international criminal law is also comprised of three elements (Paragraph 25 Subpart 1 of the Rome Statute from 1998). These are ${ }^{52}: 1$ ) being above the age of 18,2$)$ mental competence and 3) guilt.

These elements of criminal responsibility are assessed in each individual case according to the time of conduct of the actual criminal offence. As such, they represent the grounds of subjective and personal (individual) criminal responsibility, which is a precondition for the enforcement of penalty to the person, who committed some of the crimes against international law.

Furthermore, it is prescribed in Paragraph 27 of the Rome Statute that it shall apply equally to all persons without any distinction based on their official capacity. In particular, official capacity as a Head of State or Government, a member of Government or Parliament, an elected representative or a government official shall in no case exempt a person from criminal responsibility nor shall it, in and of itself, constitute a ground for reduction of sentence. Therefore, immunities based upon national or international laws (in accordance with the provisions of the Vienna Convention) do not represent an obstacle for the International Criminal Court to exercise its jurisdiction ${ }^{53}$.

Mental competence represents a group of subjective or intellectual elements (elements of consciousness) and elements of will that enable the perpetrator under international law to reason (to understand the significance of his act) and to make decisions (to control his acts). It is the foundation (basis) of guilt and stands for "general previous capability" of a person to be responsible for the crime against international law he has

\footnotetext{
${ }^{51}$ More: N. A. Combs, Guilty pleas in International Criminal Law, Stanford, 2007.

${ }^{52}$ N. Jorgensen, The Responsibility of States for International Crimes, Oxford, 2000. pp. 45-58.

${ }^{53}$ D. Radulović, Međunarodno krivično pravo, Podgorica, 1999. p. 91.
} 
The Criminal Responsibility for the Genocide and the Crime against Humanity According ...

committed. Nevertheless, mental competence can be excluded or more or less significantly diminished, depending on the presence of particular mental disorders and their impact on the psychological capabilities of the perpetrator. Legally relevant mental disorders include the following: 1) permanent or temporary mental illness, 2) temporary mental disorder and 3) mental retardation.

If it is confirmed that the perpetrator under international law was mentally capable at the time of conduct, which is the precondition for the enforcement of punishment, the presence of his guilt should also be assessed. Guilt is a psychological relation of the offender towards the committed crime against international law as an act of his own. Guilt is present when the offender is aware of the act, the consequence and the causal relation between them, as well as of all the essential characteristics of the committed criminal offence.

Depending on the forms of perpetrator's consciousness and will, legal theory is familiar with two forms of guilt ${ }^{54}$ : 1) premeditation and 2) negligence.

In Paragraph 30 of the Rome Statute the psychological element is defined within the frames of individual criminal responsibility (which is set in the provisions of Paragraph 25 of the Statute) by saying that criminal responsibility exists if criminal offence is committed with intent and knowledge. This means that the perpetrator has to own consciousness and knowledge about the circumstances of his act or about the fact that the consequence of the act will emerge from the expected sequence of events. This provision indicates that the Rome Statute is familiar only with premeditation as a form of guilt of the offender against international criminal law. Still, the institution of responsibility of a superior allows the military or civil superior to be responsible even when acting negligently for the criminal offences committed by his subordinates (persons under his control or supervision).

Premeditation ${ }^{55}$ (dolus) is comprised of two fundamental elements. These are: a) consciousness, awareness, knowledge of the committed criminal offence, i.e. of all the characteristics of its essence and $b$ ) will or determination to cause the foreseen consequence of the act. The majority of crimes against international law are committed by premeditation as the form of perpetrator's guilt. However, some crimes against international law can be committed only by premeditation in the narrow sense, i.e. direct or special premeditation.

This type of premeditation includes the intent of the perpetrator as the highest and the most intensive form of conscious and willing determination of a person's act towards causing the consequence. At the end, it is worth saying that, besides mental capacity and guilt, the Rome Statute explicitly determines the age of the perpetrator (above 18 years) at the time of conduct as a precondition for criminal responsibility of the offender against international criminal law.

\section{Grounds for excluding criminal responsibility}

The precondition for the offender against international criminal law to be liable for punishment is the presence of his criminal responsibility at the time of conduct. Nevertheless, the Rome Statute is familiar with several circumstances (grounds) that exclude

\footnotetext{
${ }^{54}$ Lj. Lazarević, Komentar Krivičnog zakonika Srbije, Beograd, 2005. pp. 67-71.

${ }^{55}$ D. Jovašević, Krivično pravo, Opšti deo, Beograd, 2016. pp. 185-187.
} 
criminal responsibility. Among these grounds, one can also find some circumstances that particular national criminal legal provisions generally do not consider as grounds for excluding criminal responsibility, and as grounds for excluding criminal act in general or as grounds for remittance of punishment. ${ }^{56}$

The Rome Statute is familiar with several grounds for excluding criminal responsibility. The following grounds are enumerated in Paragraph $31^{57}$ : 1) mental incompetence, 2 ) intoxication, 3) self-defense, and 4) extreme necessity.

In Paragraph 32, the Rome Statute describes mistake of fact and mistake of law as grounds for reducing criminal responsibility of the offender against criminal law, whereas in Paragraph 33 two more grounds of this kind are mentioned. These are: 1) superior orders and 2) prescription of law.

\section{Mental incompetence}

Mental incompetence is the first ground for excluding criminal responsibility, not only under national, but under international criminal law, as well. This term means that an offender against international criminal law was unable to reason (i.e. to appreciate the unlawfulness of his act) and to make decisions at the time of conduct due to mental illness or disorder that disabled him from appreciating the unlawfulness or the nature of his behavior, as well as from coordinating his behavior with the behavior that is legally acceptable.

The aforesaid indicates that mental incompetence is comprised of two fundamental elements ${ }^{58}:$ 1) biological and 2) psychological.

The biological element of mental incompetence consists of mental disorder, i.e. certain forms of disorders that affect normal conduct of perpetrator's psychological processes. Such mental disorder can emerge as $\left.{ }^{59}: 1\right)$ permanent or temporary mental illness, 2) temporary mental disorder and 3) mental retardation.

\footnotetext{
${ }^{56}$ In legal theory, the following circumstances are also considered as grounds for reducing criminal responsibility: 1) an offence of minor significance, since jurisdiction of international criminal courts (tribunals) is established only for grave, serious, and long-lasting violations of international humanitarian law, 2) the fact that the offender against international law is under 18 , when international judiciary authorities cannot have jurisdiction over such offender, and national judiciary authorities can, 3) the fact that a criminal offence is not prescribed as such by the law, when the act is not considered as punishable under national or international criminal law if at the time of conduct it has not been prescribed as such by criminal law (national criminal legislation) or by an international legal document, 4)the fact that criminal offence has been committed with victim's consent, if such criminal offence includes the absence of victim's consent as its essential element (for example, rape, forced labor, forced deportation of population) and 5) the fact that criminal offence has been committed under coercion, i.e. duress (meaning that the victim was coerced by threat of grave and permanent (irreversible) consequence such as murder or bodily harm and had no actual power to prevent the consequence of the offence). The following circumstances are also pointed out as grounds for reducing criminal responsibility for a crime against international law: 1) the consent of the victim, 2) diplomatic immunity, 3) military necessity during an armed conflict, 4) lawful repression-contra measures and 5) the tu quoque argument.

${ }^{57}$ B. Petrović, D. Jovašević, Krivično (kazneno) pravo Bosne i Hercegovine, Opći dio, Sarajevo, 2005. pp. 223-233.

${ }^{58}$ Lj. Jovanović, D. Jovašević, Krivično pravo, Opšti deo, Beograd, 2003. pp. 154-157.

${ }^{59}$ D. Jovašević, Međunarodno krivično pravo, Niš, 2011. pp. 59-63.
} 
The Criminal Responsibility for the Genocide and the Crime against Humanity According ...

The psychological element of mental incompetence includes two types of incapacity

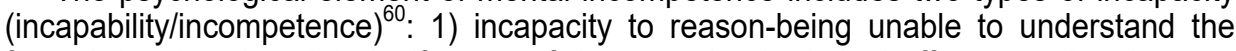
factual, legal and social significance of the committed criminal offence against international law or, as it is called in the Rome Statute, "incapacity to appreciate the unlawfulness of one's conduct" and 2) incapacity to make decisions-being unable to control one's conduct to conform to the requirements of his consciousness.

Such incapacity (incompetence) is assessed during criminal procedure with the help of findings and opinion given by psychiatric expert witness (Paragraph 31, subpart 1, point "a" of the Rome Statute). Here should be pointed out that although the Rome Statute intends to define a considerable amount of fundamental terms and institutions of the general part of international criminal law, it fails to mention the institution of "substantially diminished mental competence" (recognized by the majority of contemporary national criminal legislation).

Substantially diminished mental competence is a psychological condition of the perpetrator at the time of conduct that, due to a certain form of mental disorder, leads to substantial (significant) diminishment (but not to complete exclusion) of the capacity to reason or make decisions. The fact that the Rome Statute is not familiar with the institution of substantially diminished mental competence does not represent an obstacle for the Court Chamber to take this circumstance (i.e. grade of guilt) into account when determining the punishment for the perpetrator and treat it as an extenuating circumstance in accordance with Paragraph 78, subpart 1 of the Rome Statute (which has generally been applied in the practice of the Hague Tribunal so far).

\section{Intoxication}

The second ground for reducing criminal responsibility under international criminal law is defined in Paragraph 31, subpart 1, point "b" of the Rome Statute. It includes intoxication or inebriation (meaning the presence of contemporary mental disorder of the perpetrator, which has been induced in a specific manner). This ground is fulfilled when the perpetrator was brought to the condition of intoxication or inebriation (by alcohol or drug abuse or otherwise) that destroyed his capacity to appreciate the unlawfulness or the nature of his conduct, or his capacity to control his conduct to conform to the requirements of law. ${ }^{61}$

In this case, offender's capacity to reason or to make decisions at the time of conduct is not excluded because one of the forms of mental disorder is indicated due to the intoxication or the inebriation of the offender himself. Namely, perpetrator's mental competences (capacities) are excluded because of the effects of alcohol, drugs or similar intoxicating substances. This means that at the time of conduct the perpetrator is in the condition of intoxication, i.e. inebriation, in which he does not possess a completely preserved capacity to understand the significance of his act or to control his conduct. However, the use of this institution under international criminal law requires that the perpetrator was brought to the condition of intoxication without his guilt and without his active contribution ${ }^{62}$.

\footnotetext{
${ }^{60}$ B. Ivanišević, G. Ilić, T. Višnjić, V. Janjić, Vodič kroz Haški tribunal, Beograd, 2007. pp. 157-164.

${ }^{61}$ V. Đ. Degan, B. Pavišić, Međunarodno kazneno pravo, Zagreb, 2005. pp. 468-470.

${ }^{62}$ M. Goreta, Osvrt na koncept smanjene ubrojivosti koji se primenjuje na međunarodnom kaznenom sudu za područje bivše Jugoslavije, Društveno istraživanje, Zagreb, No. 1, 2003. pp. 247-258.
} 
Actually, the Rome Statute explicitly forbids this institution to be applied if the perpetrator voluntarily caused his state of intoxication and committed a criminal offence in such state. In such situation, there is an institution in legal theory known as actiones liberae in causa (acts that have been voluntarily caused, but not voluntarily committed), which means that the perpetrator voluntarily brought himself to such condition, being familiar with the risk of commencing the act that represent a crime against international law, but disregarding it due to intoxication. Criminal responsibility of such perpetrator cannot be excluded.

\section{Self-defense}

Self-defense is a ground for excluding criminal responsibility provided by Paragraph 31 , subpart 1, point "c" of the Rome Statute. There is self-defense if the perpetrator committed a crime against international law in order to repel a concurrent unlawful attack on his person or another person. In view of that, self-defense, as a ground for excluding criminal responsibility, is interpreted as "individual self-defense" and not as "collective self-defense" that is recognized as the right of every state by Paragraph 51 of the UN Charter. This ground for reducing criminal responsibility requires that the following conditions are met $^{63}$ :

1) That crime against international law is committed by a person, who acts reasonably (rationally),

2) That the person committed the offence in order to defend himself or another person or, in the case of war crimes, in order to defend property, which is essential for their survival or property, which is essential for accomplishing a military mission.

Therefore, this institution is applied not only in the case of self-defense, but in the case of "necessary help", i.e. defense of another person, as well. Moreover, the use of this institution has been expanded, since it does not refer only to the protection of life and physical integrity, but also to the protection of property (however, not in all situations, but only when the protection of such property is of existential importance or essential for accomplishing a military mission, which indicates the use of "war necessity"),

3) That the offence is committed with the intent to protect the mentioned values from an imminent (actual or impending) and unlawful (illegal) use of force and

4) That the offence is committed in a manner proportionate to the degree of danger to the person or the other person or property protected.

However, the fact that a person was involved in a defensive operation conducted by military forces does not in itself constitute a ground for excluding criminal responsibility. Accordingly, the use of self-defense under international criminal law differs from its use under national criminal legislation in two aspects $\left.{ }^{64}: 1\right)$ international criminal law allows this institution to be used not only in the case of personal rights' protection, but also when the property of the perpetrator or another person (presumably a person who is close to him) is protected and 2) the character of a military mission is irrelevant for the use of this institution.

\footnotetext{
${ }^{63}$ D. Jovašević, Nužna odbrana i krajnja nužda, Niš, 2008. pp. 67-85.

${ }^{64}$ D. Jovašević, T. Hašimbegović, Osnovi isključenja krivičnog dela, Beograd, 2001. pp. 58-69.
} 


\section{Extreme necessity}

The institution of extreme necessity ${ }^{65}$ is defined in Paragraph 31, subpart 1, point "d" of the Rome Statute. It represents a particular ground for excluding criminal responsibility under international criminal law. Extreme necessity is present if the perpetrator committed a criminal offence in order to repel from his person or another person a concurrent unprovoked danger that could not be otherwise repelled, and the damage inflicted does not exceed the damage threatened ${ }^{66}$. This means that a person who commits a crime against international law under the following conditions is not considered as criminally responsible ${ }^{67}$ :

1) That the perpetrator was under duress resulting from a threat of imminent death or of continuing or imminent serious bodily harm against him or another person. Such duress may either be made by other person or persons or constituted by other independent circumstances that are beyond perpetrator's control,

2) That the duress should either have occurred or be imminently threatening the perpetrator or another person. Namely, the duress that is repelled in this manner can come from other persons or from other circumstances that are beyond perpetrator's control, and

3 ) That when repelling the duress the perpetrator acts necessarily and reasonably provided that the harm he caused is not greater than the one sought to be avoided in this manner.

\section{Mistake}

The Rome Statute deals with mistake of fact and mistake of law in Paragraph 32. Both cases include an incorrect or incomplete knowledge (awareness) of a particular circumstance. Mistake of fact is present when the error refers to a factual circumstance that constitutes the essence of a crime against international law. On the other hand, mistake of law represents a misconception related to the unlawfulness of the committed crime against international law.

Mistake of fact excludes criminal responsibility if the perpetrator does not hold a correct and complete perception of the psychological element, i.e. the element of intention or consciousness that constitutes the essence of a particular crime against international law. Accordingly, mistake of fact excludes perpetrator's premeditation. It can appear in two forms ${ }^{68}: 1$ ) as an error related to a particular circumstance that represents an essential characteristic of a crime against international law-mistake of fact in the narrow sense and 2) as an error related to a particular circumstance that excludes the unlawfulness of

\footnotetext{
${ }^{65}$ M. Babić, Krajnja nužda u krivičnom pravu, Banja Luka, 1987. pp. 78-108.

${ }^{66}$ Extreme necessity is used under international criminal law when the following conditions are met: 1) that a person committed a criminal offence under the circumstances that include a direct threat of grave and permanent consequence for life or physical integrity of that person, 2) that there was no other appropriate means to repel such threat, 3 ) that the damage inflicted does not exceed the damage threatened, and 4) that the person did not willfully contribute to the situation that forced him to act under extreme necessity or coercion.

${ }^{67}$ LJ. Bavcon, A. Šelih, Kazensko pravo, Splošnij del, Ljubljana, 1987. pp. 151-156.

${ }^{68}$ B. Petrović, D. Jovašević, Krivično (kazneno) pravo Bosne i Hercegovine, Opći dio, Sarajevo, 2005. pp. 163-166.
} 
the act. Such circumstance, known as mistake of fact in the broader sense, stands beyond the essence of a criminal offence, but it is of criminal legal nature. If it existed in reality, it would exclude the unlawfulness of the committed criminal offence.

Mistake of law or mistake in the use of law (provided by Paragraph 32, subpart 2 of the Rome Statute) is related to perpetrator's decision upon whether his behavior represents a crime against international law. It can exclude criminal responsibility in the following cases ${ }^{69}$ : 1) when perpetrator's mistake can exclude his premeditation, i.e. if the perpetrator was not aware or did not appreciate at the time of conduct the psychological element required by a particular criminal offence and 2) when the mistake excludes perpetrator's guilt, i.e. in the case of superior orders or prescription of law (Paragraph 33 of the Rome Statute).

\section{Superior order and prescription of law}

The last ground for reducing criminal responsibility under international criminal law is provided by Paragraph 33 of the Rome Statute. It includes: 1) superior order and 2) prescription of law.

To be more precise, according to this explicit provision, the fact that a crime against international law has been committed by a person pursuant to an order of a military or civil state authority or prescription of law does not relieve that person of criminal responsibility unless: 1) the person was under a legal obligation to obey orders of the Government or the superior in question, 2) the person did not know that the order was unlawful and 3 ) the order was not manifestly unlawful.

However, it is explicitly pointed out that orders to commit genocide or crimes against humanity are to be considered as manifestly unlawful, which means that it is not possible to apply this ground for reducing criminal responsibility when dealing with the gravest crimes against international law. Still, this ground can be applied when excluding criminal responsibility for war crimes.

\section{The responsibility of a superior (the command responsibility) ${ }^{70}$}

\section{Notion and elements of command responsibility}

Under international criminal law as well, subjective criminal responsibility, based upon age, mental competence and guilt, represents a precondition for the enforcement of criminal sentences to the offenders against international criminal law. This is personal (individual) subjective responsibility that excludes criminal responsibility for the acts of another person, i.e. objective responsibility. After having taken into consideration all the examined personal and material evidence, the international criminal judiciary authority in charge has to assess whether all psychological elements (elements of consciousness

\footnotetext{
${ }^{69}$ D. Jovašević, Lj. Mitrović, V. Ikanović, Krivično pravo Republike Srpske, Opšti deo, Banja Luka, 2017. pp. 211-227.

${ }^{70}$ There are authors who prefer to use terms such as "commanding" responsibility, responsibility of a superior, responsibility of a commander and responsibility for the act of another person instead of the term "command" responsibility.
} 
The Criminal Responsibility for the Genocide and the Crime against Humanity According ...

and elements of will) were encompassed by the offender (perpetrator or accomplice) at the time of conduct in each particular case. That is the rule.

However, the nature and character of crimes against international law caused one more ground for punishing the perpetrators of these criminal offences known as the responsibility of a superior. A consistent terminological definition of this term has not yet been established in legal theory. Hence, the following terms are being used: superior responsibility, responsibility for conduct of subordinates, indirect superior responsibility, responsibility for failure to act and liability of a commander for the acts of his subordinates. This form of criminal responsibility under international criminal law is nowadays provided by Paragraph 28 of the Rome Statute ${ }^{71}$.

Further theoretical and practical development of responsibility of a superior ${ }^{72}$ under international criminal law is linked to the case of General Tomoyuki Yamashita, the commander of Japanese forces at Philippines, who was accused by the USA Military Commission in 1945 of crimes committed on the battlefields in the Far East during the World War II, since "the crimes were so widespread that Yamashita must have known about them, but he neglected and failed to fulfill his duty as a commander to supervise the conduct of his army by allowing it to commit serious crimes and violate the laws of war". The court found General Yamashita guilty as charged and sentenced him to death by hanging executed on February $23^{\text {rd }} 1946$.

Former Yugoslav Manual on implementation of the provisions of the international law of war in the armed forces of former SFR Yugoslavia adopted in $1988^{73}$ was familiar with the same form of responsibility for the acts of subordinates. Some cases of responsibility for the acts of subordinates are enumerated in Paragraph 21 of the Manual ${ }^{74}$ :

1) A military commander is personally responsible for the violations of the laws of war if he knew or could have known that forces or individuals under his command were preparing to breach those laws, but failed to undertake measures to prevent it.

2) A military commander is personally responsible if he knows that the breach of the laws of war has already been committed, but fails to accuse the persons responsible for such violations of laws.

3) A military commander, who is not empowered to accuse these persons and who failed to report them to the military commander in charge is also personally responsible.

4) A military commander is responsible as a perpetrator or as an inciter if, by failing to undertake measures against the perpetrator under international law, enables his subordinates to continue the commission of such criminal offences.

\footnotetext{
${ }^{71}$ Ž. Burić, Zapovjedna odgovornost, Hrvatska pravna revija, Zagreb, No. 11, 2004. pp. 75-79.

${ }^{72}$ When the nature of responsibility of a superior in concerned, a consistent standpoint has not yet been established in legal theory. Therefore, according to the theory that originates from common law, responsibility of a superior is considered as a form of responsibility for a crime committed by another person (i.e. by a subordinate). This standpoint is adopted in the practice of the Hague Tribunal and the Rwanda Tribunal, as well. According to another standpoint, responsibility of a superior represents responsibility for a particular criminal offence that differs from the crime committed by a subordinate. Actually, this is the case of responsibility for failure to act, i.e. for failing to conduct the necessary supervision by the commander.

${ }^{73}$ Official Military Gazette of the SFR Yugoslavia, No. 10/1988

${ }^{74}$ I. Brkić, Zapovjedna kaznena odgovornost i načelo zakonitosti u međunarodnom kaznenom pravu, Hrvatska pravna revija, Zagreb, No. 8, 2001. pp. 80-82.
} 


\section{The command responsibility according to the Rome Statute}

The entire Paragraph 28 of the Rome Statute from 1998 is dedicated to responsibility of commanders and other superiors. A military commander or person effectively acting as a military commander is criminally responsible for crimes against international law committed by forces under his effective command and control, as a result of his failure to exercise control properly over such forces, in two situations ${ }^{75}: 1$ ) when he either knew or, owing to the circumstances at the time, should have known that his forces committed or were about to commit such crimes or 2) when he failed to take all necessary and reasonable measures within his power to prevent the commission of such crimes or to submit the matter to the competent authorities for investigation and prosecution.

The superior shall also be criminally responsible for the criminal offences committed by his subordinates under his effective control, as a result of his failure to exercise control properly over such subordinates in the following cases ${ }^{76}: 1$ ) when the superior either knew, or consciously disregarded information, which clearly indicated that his subordinates committed or were about to commit such crimes, 2) when the crimes concerned activities that were within the effective control and responsibility of the superior and 3) when the superior failed to take all necessary and reasonable measures within his power to prevent the commission of the crimes or to submit the matter to the competent authorities for investigation and prosecution.

According to the standpoints adopted in legal doctrine, several conditions have to be fulfilled cumulatively in order to constitute responsibility of the superior ${ }^{77}$ :

1) that an individual or an entire military unit, subordinated to a particular military superior or political superior in the state hierarchy, committed a crime against international law within the jurisdiction of the permanent International Criminal Court, whose seat is at the Hague,

2) that the subordinate (who is the direct perpetrator) was under his superior's effective control at the time of conduct, i.e. that the superior had actual power over the subordinate,

3 ) that the superior neither ordered the commission of a crime against international law nor participated in it as a co-perpetrator or an accomplice,

4) that the superior either knew or, owing to the circumstances at the time, could have known that his subordinate committed or was about to commit a crime against international law and

5 ) that the superior failed to undertake all the necessary and reasonable ${ }^{78}$ measures within his power to prevent the commission of a crime against international law or to initiate criminal prosecution of the perpetrator if the criminal offence had already been committed.

\footnotetext{
${ }^{75}$ D. Derenčinović, Kritički o institutu zapovjedne odgovornosti u međunarodnom kaznenom pravu, Zbornik Pravnog fakulteta u Zagrebu, Zagreb, No. 1, 2001. pp. 23-44.

${ }^{76}$ F. Bačić, Zapovjedna odgovornost, posebno sa osvrtom na ratne zločine prema Ženevskim humanitarnim konvencijama, Hrvatski ljetopis za kazneno pravo i praksu, Zagreb, No. 2, 2001. pp. 139-146.

${ }^{77}$ B. Kozjak, Zapovjedna odgovornost u međunarodnom i hrvatskom kaznenom pravu, Odvjetnik, Zagreb, No. 5-6, 2001. pp. 37-40.

${ }^{78}$ This is a special form of failure to act comprised of failing to undertake necessary and reasonable measures against the direct perpetrator of crimes against international law.
} 


\section{Responsibility of a superior according to the criminal law of the Republic of Serbia}

Criminal legal system of the Republic of Serbia decisively supports the standpoint according to which criminal responsibility as a personal (individual) and subjective responsibility of a perpetrator or an accomplice represents the ground for enforcement of penalties and other criminal sentences. Apart from subjective criminal responsibility, the latest Criminal Code from 2005 is familiar with the institution of responsibility of a superior, as well.

Actually, responsibility of a superior as a form of "objective" responsibility is also provided by the Statute of the permanent International Criminal Court and can be applied by national judiciary authorities in criminal proceedings against the persons who committed some of the criminal offences from Chapter 34 of the Criminal Code entitled "Criminal Offences Against Humanity And Other Rights Guaranteed by International Law" "79.

In accordance with these solutions, the new Criminal Code of the Republic of Serbia from 2005 actually stipulates criminal responsibility and liability for punishment in the case of "responsibility of a superior" in Paragraph 384 under the title "Failure to Prevent Crimes against Humanity and other Values Protected under International Law". In fact, this provision stipulates a particular crime against international law that is comprised of failure to act. There are several forms of this criminal offence.

This legal provision also stipulates a particular form of criminal responsibility of a person, who does not undertake the necessary measures to prevent the commission of the following criminal offences against humanity and other rights guaranteed by international law $^{80}:$ 1) genocide, 2) crime against humanity, 3) war crime against civilian population, 4) war crime against the wounded and sick, 5) war crime against the prisoners of war, 6) employment of prohibited means of warfare, 7) unlawful killing and wounding of enemy, 8) unlawful appropriation of objects from bodies, 9) violation of protection granted to bearer of flag of truce/emissary, 10) cruel treatment of the wounded, sick and prisoners of war and 11) destroying cultural heritage.

These acts actually represent preparation for commission or commission of the gravest criminal offences today.

The first form of this criminal offence can be committed by a military commander or a person, who discharges such function in practice. It is therefore a criminal offence that can be committed only by a perpetrator with particular characteristics, i.e. delicta propria. This criminal offence includes the following three elements ${ }^{81}: 1$ ) that the perpetrator was aware or conscious of the fact that other persons conducted preparations or directly committed the enumerated crimes against international law, 2) that crimes against international law were committed by the persons, who entered the forces within the perpetrator's command or control and 3) that the perpetrator did not undertake (failed to undertake) the measures that he could have and was obliged to undertake in order to prevent the commission of the abovementioned crimes against international law, which actually resulted in their commission.

\footnotetext{
${ }^{79}$ V. Đurđić, D. Jovašević, Krivično pravo, Posebni deo, Beograd, 2006. pp. 336-337.

${ }^{80}$ D. Jovašević, Međunarodna krivična dela - odgovornost i kažnjivost, Niš, 2010. pp. 182-188.

${ }^{81}$ B. Ivanišević, G. Ilić, T. Višnjić, V. Janjić, Vodič kroz Haški tribunal, Beograd, 2007. pp. 133-151.
} 
The punishment prescribed for this criminal offence is the same punishment that would be imposed on the direct perpetrator of some of the enumerated crimes against international law.

Hence, the fact that some of the abovementioned criminal offences were committed by a subordinate does not absolve his superior from criminal responsibility.

The second form of this criminal act from Paragraph 384 of the New Criminal Code of the Republic of Serbia is related to the failures of other superiors to act, which resulted in the commission of the mentioned crimes against international law. This criminal offence requires that three following elements are met $^{82}: 1$ ) that the perpetrator knew or was aware of the fact that other persons prepared or directly commenced the commission of the enumerated crimes against international law, 2) that these crimes against international law were committed by perpetrator's subordinates, i.e. the persons who were subordinated to him in the execution of their tasks and 3) that the perpetrator did not undertake (failed to undertake) the measures that he could have and was obliged to undertake in order to prevent the commission of the abovementioned crimes against international law, which actually resulted in the commission of these acts ${ }^{83}$.

The punishment prescribed for this criminal offence is the punishment of imprisonment that can be imposed on the direct perpetrator of one of the enumerated crimes against international law. If one of the forms of this criminal offence was committed by negligence as a form of guilt, an imprisonment of six months to five years is prescribed.

\section{Conclusion}

Established within the frames of international law of war and international humanitarian law, international criminal law obtained its "citizenship" at the beginning of the third millennium as the newest criminal legal discipline. When the Rome Statute of the International Criminal Court came into force, this branch of law was finally inaugurated in substantial, procedural and executive sense. Even earlier than that, this branch of law had evolved through the development of basic criminal legal terms and institutions within a series of international legal documents (of universal and regional character) or contracts between individual states, as well as through the practice of the courts (first of all, the practice of the Nürnberg and Tokyo Tribunals).

The latter includes the following: 1) crime against international law (which differs from a criminal offence with an international element) that can emerge in two forms: as a crime against international law in the narrow sense (genuine) or as a crime against international law in the broader sense (counterfeit or mixed), 2) criminal responsibility of the perpetrator (the precondition for criminal responsibility is the fact that the perpetrator is more than 18 years old), who can appear either as one person or include several persons or even a legal person such as a state or an organization, and 3) the system of

\footnotetext{
${ }^{82}$ P. Novoselec, Temeljne crte novele Kaznenog zakona (Zapovjedna odgovornost), Hrvatski ljetopis za kazneno pravo i praksu, Zagreb, No. 2, 2003. pp. 258.276.

${ }^{83}$ D. Kos, Zapovjedna kaznena odgovornost, Zbornik radova, Aktuelna pitanja kaznenog zakonodavstva, Zagreb, 2004. pp. 42-60
} 
The Criminal Responsibility for the Genocide and the Crime against Humanity According ...

criminal sentences, i.e. punishments that are being imposed by the supranational judiciary authorities. These fundamental terms and institutions of international criminal law are discussed in this paper.

Due to the nature, character and hazard of crimes against international law, this branch of law is familiar with a special form of objectified responsibility besides individual criminal responsibility. It is the responsibility of political and military superiors for the crimes against international law committed by their subordinates, known as the responsibility of a superior, which is entering national criminal legislation through relevant international standards. Accordingly, the Criminal Code of the Republic of Serbia from 2005 with several novels also includes this institution.

\section{Literature}

[1] Official Gazette of the Republic of Serbia, No. 85/2005, 88/2005, 107/2005, 72/2009, 111/2009, 104/2012, 108/2014 and 94/2016.

[2] D. Jovašević, Krivični zakonik Republike Srbije sa uvodnim komentarom, Beograd, 2007.

[3] S. Zadnik, Kaznena djela protiv vrijednosti zaštićenih međunarodnim pravom i novine u zakonodavstvu u svezi sa tim djelima, Hrvatska pravna revija, Zagreb, No. 12, 2003.

[4] D. Jovašević, Leksikon krivičnog prava, Beograd, 2011.

[5] D. Jovašević, Međunarodno krivično pravo, Niš, 2011.

[6] Ch. M. Bassiouni, Crimes against Humanity in International Criminal Law, Dordrecht, 1992.

[7] B. Petrović, D. Jovašević, Međunarodno krivično pravo, Sarajevo, 2010.

[8] D. Jovašević, V. Ikanović, Međunarodno krivično pravo, Banja Luka, 2015.

[9] V. Đ. Degan, B. Pavišić, Međunarodno kazneno pravo, Zagreb, 2005.

[10] D. Radulović, Međunarodno krivično pravo, Podgorica, 1999.

[11] D. Jovašević, Krivično pravo, Opšti deo, Beograd, 2016.

[12] V. Đurđić, D. Jovašević, Međunarodno krivično pravo, Beograd, 2003.

[13] D. Jovašević, Krivično pravo, Posebni deo, Beograd, 2017.

[14] B. Pavišić, T. Bubalović, Međunarodno kazneno pravo, Rijeka, 2013. pp. 283-291.

[15] I. Josipović, D. Krapac, P. Novoselec, Stalni međunarodni kazneni sud, Zagreb, 2001.

[16] D. Jovašević, Međunarodna krivična dela - odgovornost i kažnjivost, Niš, 2010.

[17] P. Novoselec, Opći dio kaznenog prava, Zagreb, 2004.

[18] A. Cassese, P. Gaeta, J. R. W. Jones, The Rome Statute of the International Criminal Court-Commentary, Oxford, New York, 2002.

[19] V. Đurđić, D. Jovašević, Krivično pravo, Posebni deo, Beograd, 2012.

[20] B. Petrović, D. Jovašević, Krivično (kazneno) pravo II, Posebni dio, Sarajevo, 2005.

[21] Official gazette of the SFR Yougoslavia No. 56/1950.

[22] B. Petrović, D. Jovašević, A. Ferhatović, Krivično pravo 2, Sarajevo, 2016.

[23] LJ. Lazarević, B. Vučković, V. Vučković, Komentar Krivičnog zakonika Crne Gore, Cetinje, 2004.

[24] B. Pavišić, V. Grozdanić, P. Veić, Komentar Kaznenog zakona, Zagreb, 2007.

[25] D. Jovašević, Lj. Mitrović, V. Ikanović, Krivično pravo Republike Srpske, Posebni deo, Banja Luka, 2017.

[26] K. Turković et al., Komentar Kaznenog zakona, Zagreba, 2013. 
[27] F. Bačić, Krivično pravo, Posebni deo, Zagreb, 1986.

[28] V. Đ. Degan, B. Pavišić, V. Beširević, Međunarodno i transnacionalno krivično pravo, Beograd, 2013.

[29] Official Gazette of the Republic of Serbia No. 85/2005, with more novels to 2016. 2007.

[30] D. Jovašević, The Criminal code of the Republic of Serbia with commentary, Belgrade,

[31] Z. Pajić, Tumačenje zločina protiv čovečnosti u nirnberškom procesu, Godišnjak Pravnog fakulteta u Sarajevu, Sarajevo, 1991.

[32] M. Milojević, Zločin protiv čovečnosti u rezolucijama Generalne skupštine UN, Godišnjak Pravnog fakulteta u Sarajevu, Sarajevo, 1978.

[33] N. A. Combs, Guilty pleas in International Criminal Law, Stanford, 2007.

[34] N. Jorgensen, The Responsibility of States for International Crimes, Oxford, 2000.

[35] Lj. Lazarević, Komentar Krivičnog zakonika Srbije, Beograd, 2005.

[36] B. Ivanišević, G. llić, T. Višnjić, V. Janjić, Vodič kroz Haški tribunal, Beograd, 2007.

[37] M. Goreta, Osvrt na koncept smanjene ubrojivosti koji se primenjuje na međunarodnom kaznenom sudu za područje bivše Jugoslavije, Društveno istraživanje, Zagreb, No. 1, 2003.

[38] D. Jovašević, Nužna odbrana i krajnja nužda, Niš, 2008.

[39] D. Jovašević, T. Hašimbegović, Osnovi isključenja krivičnog dela, Beograd, 2001.

[40] M. Babić, Krajnja nužda u krivičnom pravu, Banja Luka, 1987.

[41] LJ. Bavcon, A. Šelih, Kazensko pravo, Splošnij del, Ljubljana, 1987.

[42] Ž. Burić, Zapovjedna odgovornost, Hrvatska pravna revija, Zagreb, No. 11, 2004.

[43] Official Military Gazette of the SFR Yougoslavia No. 10/1988.

[44] I. Brkić, Zapovjedna kaznena odgovornost i načelo zakonitosti u međunarodnom kaznenom pravu, Hrvatska pravna revija, Zagreb, No. 8, 2001.

[45] D. Derenčinović, Kritički o institutu zapovjedne odgovornosti u međunarodnom kaznenom pravu, Zbornik Pravnog fakulteta u Zagrebu, Zagreb, No. 1, 2001.

[46] F. Bačić, Zapovjedna odgovornost, posebno sa osvrtom na ratne zločine prema Ženevskim humanitarnim konvencijama, Hrvatski ljetopis za kazneno pravo i praksu, Zagreb, No. 2, 2001.

[47] B. Kozjak, Zapovjedna odgovornost u međunarodnom i hrvatskom kaznenom pravu, Odvjetnik, Zagreb, No. 5-6, 2001.

[48] P. Novoselec, Temeljne crte novele Kaznenog zakona (Zapovjedna odgovornost), Hrvatski ljetopis za kazneno pravo i praksu, Zagreb, No. 2, 2003.

[49] D. Kos, Zapovjedna kaznena odgovornost, Zbornik radova, Aktuelna pitanja kaznenog zakonodavstva, Zagreb, 2004. 